\title{
Impact of Inclusion of Peanut Vein Hay and Exogenous Enzymes in Diets on Performance, Nutrients Digestibility and Carcass Traits of Growing New Zealand White Rabbits
}

\author{
Doaa Mohamed Saber ${ }^{1 *}$, Mohamed Reda Ibrahim ${ }^{1}$, Mohamed Ahmed Fouad El-Manylawi ${ }^{1}$ and Marwa Abd Elmonem Suliman ${ }^{2}$ \\ ${ }^{I}$ Department of Animal Production, Faculty of Agriculture, Cairo University, Giza, Egypt \\ ${ }^{2}$ Animal Production Research Institute, Agricultural Research Center, 12618, El-Dokki, Giza, Egypt \\ *Corresponding author's E-mail: doaa.saber86@yahoo.com; ORCID: 0000-0002-7411-2369
}

\begin{abstract}
The present study examined the effect of replacing clover hay with Peanut Vein Hay (PVH) and Galzym (multienzyme) additive on growth performance and carcass traits of rabbits as well as nutritive value and economic efficiency of diets. Seventy-two growing New Zealand White rabbits aged about 6 weeks divided into six experimental treatments (12 rabbits per treatment). The experimental treatments were $\mathrm{T} 1$, control diet without Galzym; T2, control diet with Galzym; T3, 25\% PVH without Galzym; T4, 25\% PVH with Galzym; T5, 50\% PVH without Galzym and T6, 50\% PVH with Galzym. The obtained results revealed that final body weight and body weight gain significantly increased in T3 and T4 compared to T1. Rabbits on T3 consumed a higher amount of feed compared to the other groups. There were no significant differences in feed conversion ratio and carcass traits among the experimental groups. The increase in the substitution level of PVH had a significant effect on growth performance except the FCR was not significantly different. While adding Galzym to rabbit diets had no effect on growth performance. The experimental diets and substitution levels of PVH significantly affected total digestible nutrients and digestible energy. In conclusion, feeding growing rabbits with $25 \% \mathrm{PVH}$, with or without Galzym, leads to better growth performance and higher economic efficiency without any adverse effect on rabbit health.
\end{abstract}

Key words: Carcass, Enzyme, Feed intake, Rabbits

\section{INTRODUCTION}

In developing countries, population growth and reducing the availability of cultivated land for animal fodder production demand the use of unconventional feed resources for livestock ration (Tawila et al., 2008). Globally, there is large area cultivated for legume crops which results in the large quantity of their by-products. For example, FAO (2016) estimated the total area under cultivation with peanut in Egypt was about 5800 hectares. Peanut (Arachis hypogaea) is one of the most important species of Fabaceae family, produce high volume of by-products. The peanut hay is rich in protein, has better palatability and chemical composition close to clover hay, thus could be used as untraditional feedstuffs (Heuzé et al., 2017). The use of legumes hay as alternatives to Berseem hay in rabbit diet may be a good solution for feedstuff shortage and provide consumers with high-quality protein for animals. Although legumes are rich in protein, the nutritional value of leguminous proteins may be limited by the presence of anti-nutritional factors. The use of exogenous enzymes can remove the effect of anti-nutritional factors and improve the nutrient availability of legumes (Oloruntola and Ayodele, 2017).

The current work aimed to study the impact of replacing clover hay with Peanut Vein Hay (PVH), without or with Galzym (multi-enzyme), in rabbit diets on nutrients digestibility and economic efficiency of experimental diets as well as on growth performance and carcass characteristics of rabbits.

\section{MATERIALS AND METHODS}

The experiment was conducted in Rabbits Experimental Unit, Animal Production Department, Faculty of Agriculture, Cairo University, Giza, Egypt.

\section{Ethical approval}

This study was carried out after obtaining ethical approval from the Animal Production Research Institute, Egypt. The experiments were in compliance with the guidelines of Institutional Animal Care and Use Committees (IACUCs). 


\section{By-product preparation and experimental diets}

The PVH was obtained in fresh form from fields in Giza governorate, then sun-dried, grinded by hammer mill and analyzed for chemical composition according to AOAC (2000). The ingredients were blended and pelleted at manufactory of Faculty of Agriculture, Cairo University.

Galzym is a multi-enzyme produced in Tex Biosciences Ltd., India. Galzym contains cellulase 100.000.000 U/kg, xylanase 1.500.000 U/kg, lipase $10.000 \mathrm{U} / \mathrm{kg}$, amylase $125.000 \mathrm{U} / \mathrm{kg}$, protease $15.000 \mathrm{U} / \mathrm{kg}$, pectinase $30.000 \mathrm{U} / \mathrm{kg}$, arabinase $7.000 \mathrm{U} / \mathrm{kg}$, Phytase $200.000 \mathrm{U} / \mathrm{kg}$, a-galactosidase $10.000 \mathrm{U} / \mathrm{kg}$, and b-glucosidase $10.000 \mathrm{U} / \mathrm{kg}$.. Experimental diets were: control diet without PVH and Galzym (T1); control diet without PVH and with the Galzym (T2), 25\% of clover hay in basal diet replaced by PVH without Galzym (T3); 25\% of clover hay in basal diet replaced by PVH with Galzym (T4); 50\% of clover hay in basal diet replaced by PVH without Galzym (T5); 50\% of clover hay in basal diet replaced by PVH with Galzym (T6). All experimental diets (Table 1) were formulated to be isonitrogenous and isocaloric, to meet all the essential nutrient requirements of growing rabbits (Lebas, 2004). The diets and fresh water were provided ad libitum.

Table 1. Feed ingredients and chemical composition of experimental diets

\begin{tabular}{|c|c|c|c|c|c|c|}
\hline \multirow{2}{*}{ Feed ingredients } & \multicolumn{6}{|c|}{ Diets } \\
\hline & T1 & $\mathbf{T 2}$ & T3 & T4 & T5 & T6 \\
\hline Soybean meal (44\% CP) & 16.30 & 16.30 & 16.30 & 16.30 & 15.70 & 15.70 \\
\hline Yellow corn & 13.8 & 13.8 & 13.80 & 13.80 & 13.60 & 13.60 \\
\hline Barley & 13.00 & 13.00 & 13.00 & 13.00 & 13.00 & 13.00 \\
\hline Wheat bran & 16.70 & 16.70 & 16.70 & 16.70 & 17.50 & 17.50 \\
\hline Clover hay & 34.00 & 34.00 & 25.50 & 25.50 & 17.00 & 17.00 \\
\hline Peanut vein hay (PVH) & 0.00 & 0.00 & 8.50 & 8.50 & 17.00 & 17.00 \\
\hline Dl- methionine & 0.20 & 0.20 & 0.20 & 0.20 & 0.20 & 0.20 \\
\hline Di calcium phosphate & 2.20 & 2.20 & 2.20 & 2.20 & 2.20 & 2.20 \\
\hline Sodium chloride & 0.30 & 0.30 & 0.30 & 0.30 & 0.30 & 0.30 \\
\hline Vitamin and minerals primix ${ }^{1}$ & 0.30 & 0.30 & 0.30 & 0.30 & 0.30 & 0.30 \\
\hline Anti coccidia and fungi & 0.20 & 0.20 & 0.20 & 0.20 & 0.20 & 0.20 \\
\hline Molasses & 3.00 & 3.00 & 3.00 & 3.00 & 3.00 & 3.00 \\
\hline Total & 100.00 & 100.00 & 100.00 & 100.00 & 100 & 100 \\
\hline \multicolumn{7}{|l|}{ Chemical analysis (DM basis) } \\
\hline $\mathrm{DM}(\%)$ & 90.50 & 90.50 & 90.47 & 90.47 & 90.92 & 90.92 \\
\hline $\mathrm{OM}(\%)$ & 92.83 & 92.83 & 93.43 & 93.43 & 92.24 & 92.24 \\
\hline $\mathrm{CP}(\%)$ & 17.20 & 17.20 & 17.18 & 17.18 & 17.00 & 17.00 \\
\hline $\mathrm{CF}(\%)$ & 13.87 & 13.87 & 13.04 & 13.04 & 12.25 & 12.25 \\
\hline $\mathrm{EE}(\%)$ & 2.17 & 2.17 & 2.25 & 2.25 & 2.36 & 2.36 \\
\hline NFE $(\%)$ & 59.59 & 59.59 & 60.96 & 60.96 & 60.63 & 60.63 \\
\hline Ash (\%) & 7.17 & 7.17 & 6.57 & 6.57 & 7.76 & 7.76 \\
\hline $\mathrm{DE}\left(\mathrm{kcal} / \mathrm{kg}^{2}\right)$ & 2612.00 & 2612.00 & 2655.00 & 2655.00 & 2689.07 & 2689.07 \\
\hline Calcium (\%) & 0.96 & 0.96 & 0.97 & 0.97 & 0.97 & 0.97 \\
\hline Total phosphors (\%) & 0.86 & 0.86 & 0.86 & 0.86 & 0.86 & 0.86 \\
\hline
\end{tabular}

T1, control diet without Galzym; T2, control diet with Galzym; T3, 25\% PVH without Galzym; T4, 25\% PVH with Galzym; T5, 50\% PVH without Galzym and T6, 50\% PVH with Galzym. ${ }^{1}$ Commercial vitamin and mineral premix (per $3 \mathrm{Kg}$ premix) contained Vit. A 12000000 IU, Vit.D3 3000000 IU, Vit.E $10000 \mathrm{mg}$, Vit.K3 $2000 \mathrm{mg}$, Vit.B1 $1000 \mathrm{mg}$, Vit.B2 $5000 \mathrm{mg}$, Vit.B6 1500mg, Vit. B12 $10 \mathrm{mg}$, Pantothenic acid $10000 \mathrm{mg}$, Nicotenic acid $30000 \mathrm{mg}$, Folic acid $1000 \mathrm{mg}$, Biotin $75 \mathrm{mg}$, Copper $4000 \mathrm{mg}$, Manganese $80000 \mathrm{mg}$, Zinc $50000 \mathrm{mg}$, Iron $30000 \mathrm{mg}$, Iodine $500 \mathrm{mg}$, Selenium $100 \mathrm{mg}$ and Cobalt $100 \mathrm{mg}$. DM: Dry Matter, OM: Organic Matter, CP: Crude Protein, CF: Crude fiber, EE: Ether Extract, NFE: Nitrogen Free Extract, DCP: Digestible Crude Protein, TDN: Total Digestible Nutrients. ${ }^{2}$ DE $=$ Digestible Energy $(\mathrm{kcal} / \mathrm{kg})=4.36-0.049 \times[28.924+0.657(\mathrm{CF} \%)]$ according to Cheeke, (1987).

\section{Animals, housing and management}

Seventy-two growing New Zealand White rabbits aged about 6 weeks divided into six experimental groups (12 rabbits per treatment). The experimental period lasted eight weeks (6 - 14 weeks of age). Live body weight ranged from 743.33 to $764.11 \mathrm{~g}$. All rabbits were kept under the same managerial and hygienic conditions and housed in metal battery cages supplied with separated feeders. All rabbits were kept under veterinary control and vaccinated against rabbit hemorrhagic disease and rabbit pasteurellosis.

\section{Growth performance}

Final Body Weight (FBW), Feed Intake (FI), and Body Weight Gain (BWG) were recorded weekly. Feed Conversion Ratio (FCR) was calculated as FI divided by BWG during the whole experimental period. 


\section{Nutrients digestibility and nutritive value}

Eighteen rabbits were used in the digestion trial and divided into six groups of three rabbits each. Rabbits were placed in individual metabolism cages $(56 \times 38 \times 28 \mathrm{~cm})$. Feces were collected daily before the morning meal and weighed fresh and dried at $60{ }^{\circ} \mathrm{C}$ for $24 \mathrm{~h}$ in an air-drying oven (Perenz et al., 1995). The PVH, experimental diets and feces were prepared to determine moisture, ash, nitrogen, Ether Extract (EE), and Crude Fiber (CF), according to AOAC (2000). Data of quantities and chemical analysis of feed and feces were used to calculate the nutrient digestion coefficients and nutritive value for each dietary treatment, as described by Fekete (1985). Digestible Energy (DE) was calculated according to Schneider and Flatt (1975).

\section{Carcass traits}

At the end of the growing period (14 weeks of age), three rabbits were taken randomly from each treatment. The rabbits fasted about 16 hours before slaughtering and individually weighed as pre-slaughtering weight. Animals were slaughtered according to the Islamic religion instructions with a sharp knife. The empty carcass was weighted without head and giblets. The giblets (liver, heart, and kidneys) were separated and weighed. The edible giblets percentage, Total Edible Parts (TEP) and dressing percentage were calculated according to the following equations presented by Steven et al. (1981):

Dressing percentage $(\%)=($ carcass weight/ pre-slaughter weight $) \times 100$

Edible giblets $(\%)=[($ liver + heart + kidneys $) /$ pre-slaughter weight $] \times 100$

TEP $(\%)=[($ carcass weight + giblets weight $) /$ pre-slaughter weight $] \times 100$

\section{Economic efficiency}

The economic efficiency was calculated according to the following equation:

Economic efficiency $(\%)=($ Net revenue/ total feed cost $) \times 100$.

Net revenue $=($ selling price/rabbit $)-($ total feed cost/rabbit $)$.

Total cost and selling price were calculated in Egyptian pound according to the price at the time of the experiment; in December 2018, the price of $1 \mathrm{~kg}$ of live body weight was $38 \mathrm{LE}$.

\section{Statistical analysis}

Data were analyzed using general linear model using SAS software (SAS Institute, USA) by using model:

$\mathrm{Y}_{\mathrm{ij}}=\mu+\mathrm{L}_{\mathrm{i}}+\mathrm{G}_{\mathrm{j}}+(\mathrm{LG})_{\mathrm{ij}}+\mathrm{e}_{\mathrm{ij}}$

Where, $\mathrm{Y}_{\mathrm{ij}}$ is the observation of the parameter measured; $\mu$ is overall mean; $\mathrm{L}_{\mathrm{i}}$ is substitution levels of peanut vines hay effect; $G_{j}$ is the effect of Galzym additive; $(L G)_{i j}$ is the effect of interaction between substitution levels of peanut vines levels and Galzym additive and eij is random error. Duncan's multiple range test was performed to detected significant differences among means. The significant level was considered at $\mathrm{p} \leq 0.05$.

\section{RESULTS AND DISCUSSION}

\section{Chemical composition of peanut vein hay}

The proximate analysis of PVH compared to clover hay is illustrated in table 2. The Organic Matter (OM), CF, EE, Nitrogen Free Extract (NFE), calcium and total phosphorus content in PVH were lower than those in clover hay. Conversely, ash, Acid Detergent Fiber (ADF), Acid Detergent Lignin (ADL) and DE values in PVH were higher than those in clover hay. Dry Matter (DM) and Crude Protein (CP) were comparable in both clover hay and PVH. The values of the proximate analysis for PVH were close to those reported by Omar et al. (2012) but were lower than those reported by Omar et al. (2017). However, Iyeghe-Erakpotobor et al. (2006) found that groundnut haulms contain 96.94\% DM, $10.84 \% \mathrm{CP}, 30.43 \% \mathrm{CF}$, and $10.35 \% \mathrm{EE}$. The differences in chemical composition may be due to variations in the climatic and cultivation conditions.

\section{Growth performance}

The effects of experimental diets on growth performance are presented in table 3. Analysis of variance showed that FBW and BWG of rabbits on T3 and T4 were significantly $(\mathrm{p}<0.05)$ higher than those on T1 and T5. Nevertheless, FBW and BWG values for rabbits on $\mathrm{T} 4$ and $\mathrm{T} 6$ diets were significantly different compared to T2 diet. On the other hand, rabbits fed T3 diet consumed highest $(\mathrm{p}<0.05)$ amount of feed compared to the other experimental diets. Generally, FI increased in rabbit fed PVH diets compared to control groups, which may be due to PVH is more palatable than clover hay. The high FBW and BWG in T3 and T4 diets may be due to higher FI in rabbits on these diets. The analysis of variances also revealed insignificant differences in FCR values among all experimental diets. Concerning substitution levels of PVH, significant differences ( $\mathrm{p}<0.05)$ in FBW, BWG and FI were observed. However, Galzym additive did not affect growth performance parameters that may be due to lower enzyme dose and amount of substrate in experimental diets (Suliman, 2012). These results are in agreement with Iyeghe-Erakpotobor et al. (2015) who reported BWG was significantly lower for rabbits fed $40 \%$ groundnut forage than those fed $20 \%$ groundnut forage meal. Moreover, Mohamed et al. (2008) found that rabbit fed 15\% PVH diets either with or without enzyme addition had 
significantly higher body weight, BWG, and FI than those on the control group. Amaefule et al. (2011) found that FI in rabbits fed 20\% groundnut offal increased compared to control group and other groups fed 5, 10 and 15\% groundnut offal. However, different levels of groundnut offal had no significant effect on FBW, BWG, and FCR. Also, high levels of ADF and $\mathrm{ADL}$ contents of $\mathrm{PVH}$ resulted in lower rate of digest passage, consequently lower FI was recorded in rabbits fed $50 \% \mathrm{PVH}$ compared with those on $25 \% \mathrm{PVH}$. This result supported by Chiou et al. (1998) who reported the FI of growing rabbits fed lignin diet was lower than other rabbits fed cellulose, pectin and alfalfa diets, which was due to slower rate of digest passage of lignin diet.

Table 2. Chemical analysis of peanut vein hay and clover hay on dry matter basis

\begin{tabular}{|c|c|c|}
\hline Items & Peanut vein hay & Clover hay \\
\hline Dry matter $\%$ & 91.80 & 91.95 \\
\hline Organic matter $\%$ & 78.21 & 87.50 \\
\hline Crude protein $\%$ & 13.10 & 13.45 \\
\hline Crude fiber $\%$ & 20.20 & 26.00 \\
\hline Ether extract \% & 2.40 & 4.00 \\
\hline Nitrogen free extract $\%$ & 42.50 & 44.05 \\
\hline Ash\% & 21.75 & 12.50 \\
\hline \multicolumn{3}{|l|}{ Fiber fraction } \\
\hline Neutral detergent fiber $\%$ & 42.15 & 42.50 \\
\hline Acid detergent fiber $\%$ & 38.50 & 29.5 \\
\hline Acid detergent lignin $\%$ & 18.00 & 5.50 \\
\hline Calcium\% & 1.22 & 1.60 \\
\hline Phosphorus\% & 0.17 & 0.35 \\
\hline Digestible energy Kcal $/ \mathrm{kg}^{1}$ & 2292.43 & 2104.74 \\
\hline
\end{tabular}

Table 3. Growth performance of rabbits fed different experimental diets

\begin{tabular}{|c|c|c|c|c|c|}
\hline Diet & $\begin{array}{l}\text { IBW } \\
(\mathrm{g})\end{array}$ & $\begin{array}{l}\text { FBW } \\
(\mathrm{g})\end{array}$ & $\begin{array}{c}\mathbf{B W G} \\
\text { (g/day/rabbit) }\end{array}$ & $\begin{array}{c}\mathbf{F I} \\
\text { (g/day/rabbit) }\end{array}$ & $\begin{array}{c}\text { FCR } \\
\text { (g feed/g gain) }\end{array}$ \\
\hline $\mathrm{T} 1$ & 746.11 & $2064.69^{\mathrm{b}}$ & $23.55^{\mathrm{b}}$ & $79.28^{\mathrm{d}}$ & 3.36 \\
\hline $\mathrm{T} 2$ & 743.89 & $2165.81^{\mathrm{ab}}$ & $25.39^{\mathrm{ab}}$ & $81.39^{\mathrm{d}}$ & 3.21 \\
\hline $\mathrm{T} 3$ & 743.33 & $2247.77^{\mathrm{a}}$ & $26.87^{\mathrm{a}}$ & $92.45^{\mathrm{a}}$ & 3.44 \\
\hline $\mathrm{T} 4$ & 746.11 & $2241.49^{a}$ & $26.70^{\mathrm{a}}$ & $89.13^{\mathrm{b}}$ & 3.34 \\
\hline T5 & 745.00 & $2089.63^{b}$ & $24.01^{\mathrm{b}}$ & $81.17^{\mathrm{d}}$ & 3.38 \\
\hline T6 & 745.00 & $2130.26^{\mathrm{ab}}$ & $24.74^{\mathrm{ab}}$ & $85.83^{c}$ & 3.47 \\
\hline SEM & 0.64 & 0.58 & 0.21 & 0.33 & 0.45 \\
\hline \multicolumn{6}{|l|}{ p-value } \\
\hline Diet effect & 0.344 & 0.02 & 0.02 & $<0.0001$ & 0.5 \\
\hline Level substitution of PVH effect & 0.96 & 0.005 & 0.005 & $<0.0001$ & 0.5 \\
\hline Galzym additive effect & 0.83 & 0.25 & 0.25 & 0.40 & 0.48 \\
\hline
\end{tabular}

Mean values with different superscript letters in a column are significantly different ( $\mathrm{p}<0.05)$. PVH: Peanut Vein Hay; IBW: Initial Body Weight; FBW: Final Body Weight; BWG: Body Weight Gain; FI: Feed Intake; FCR: feed conversion ratio. T1, control diet without Galzym; T2, control diet with Galzym; T3, 25\% PVH without Galzym; T4, 25\% PVH with Galzym; T5, 50\% PVH without Galzym and T6, 50\% PVH with Galzym. SEM: Standard error of the mean.

\section{Digestion coefficients of nutrients and nutritive value}

Digestion coefficients and nutritive value affected by experimental diets are shown in table 4. The DM, OM, EE, and NFE were significantly $(\mathrm{p}<0.05)$ different among the different experimental diets. While digestibility of $\mathrm{CP}$ and $\mathrm{CF}$ were not affected. The digestible crude protein significantly $(\mathrm{p}<0.05)$ increased in rabbits fed $25 \% \mathrm{PVH}$ with Galzym additive. The Total Digestible Nutrients (TDN) and DE were significantly $(\mathrm{p}<0.05)$ lower in rabbit fed high levels of PVH (T5 and T6) compared to other diets. The substitution levels of PVH showed significant difference $(\mathrm{p}<0.05)$ in digestibility of DM, OM, and NFE. The TDN and DE in groups fed 50\% PVH (T5 and T6) were significantly lower than $(p<0.05)$ those in other groups. While Galzym did not significantly affect digestion coefficients and nutritive value. The results obtained in present study confirmed by Sarhan (2005) who found the inclusion of pea vine hay or pea pod hulls at 15 or $30 \%$ in the rabbit diets did not significantly affect the digestibility of nutrients. Similarly, groundnut haulms up to 70\% levels did not affect DM, CP and ADF digestibility in rabbits (Etchu et al., 2014). Moreover, Omer et al. (2018) reported that substitution berseem hay $(50 \%)$ with $\mathrm{PVH}$ had no effect on nutrients digestibility and nutritive value. In the current study, the digestion coefficients decreased with increasing the PVH level in diets. These observations may be due to increased concentration of tannins and cell wall levels in diets. Li and Zhang (1998) found that the presence of tannins decreased the nutritional value of feedstuffs for non-ruminant animals by reducing retention of protein, digestibility of dry matter and metabolic rate of gross energy as well as inhibition of digestive enzyme activity. Yaakugh and Tegbe 
(1990) reported that inclusion of brewers dried grain in pig diets resulted in increased dietary cell walls which led to lower DM digestibility.

\section{Carcass characteristics}

The effects of tested diets on carcass traits are shown in table 5. The carcass weight, dressing percentage, giblets weight, and TEP percentage increased in rabbits fed experimental diets compared to control diets, but this improvement was not significant. Also, the substitution levels of PVH had no effect on carcass traits except TEP percentage. Galzym additive to experimental diets had no effect on carcass characteristics. Ibrahim (2000) reported that peanut hay levels (22.3 and $33.5 \%$ ) had no effect on carcass traits except dressing percentage which increased in rabbits fed with peanut hay compared to control group. Asaret al. (2010) declared that diets supplemented with $25 \%$ dried faba bean straw did not significantly affect carcass characteristics of rabbit. Omer et al. (2018) reported that inclusion peanut hay in growing rabbit diets had no significant effect on dressing percentage. Omar et al. (2017) found that replacing 50\% berseem hay with PVH in the rabbit diet had no significant effect on dressing percentage.

\section{Economic efficiency}

The profitability of using PVH in growing rabbit diets depended on feed cost and growth performance (Table 6). The obtained data showed that experimental diets improved economic efficiency compared to the control diets. This finding is in line with the results of Ibrahim (2000).

Table 4. Digestion coefficients and nutritive value of growing rabbits fed different experimental diets.

\begin{tabular}{|c|c|c|c|c|c|c|c|c|c|}
\hline \multirow{2}{*}{ Diet } & \multicolumn{6}{|c|}{ Nutrients digestibility (\%) } & \multicolumn{3}{|c|}{ Nutritive value } \\
\hline & DM & OM & $\mathbf{C P}$ & $\mathbf{C F}$ & $\mathbf{E E}$ & NFE & DCP \% & TDN \% & $\begin{array}{c}\text { DE } \\
\text { Kcal/kg }\end{array}$ \\
\hline $\mathrm{T} 1$ & $60.15^{\mathrm{d}}$ & $63.70^{\mathrm{c}}$ & 75.15 & 44.92 & $75.37^{\mathrm{bc}}$ & $73.83^{\mathrm{c}}$ & $13.22^{\mathrm{ab}}$ & $65.32^{\mathrm{b}}$ & $2893.70^{\mathrm{b}}$ \\
\hline $\mathrm{T} 2$ & $64.96^{\mathrm{b}}$ & $66.90^{\mathrm{ab}}$ & 75.69 & 45.57 & $75.79^{\mathrm{b}}$ & $78.61^{\mathrm{b}}$ & $13.43^{\mathrm{a}}$ & $68.12^{\mathrm{a}}$ & $3017.85^{\mathrm{a}}$ \\
\hline $\mathrm{T} 3$ & $67.18^{\mathrm{a}}$ & $68.70^{\mathrm{a}}$ & 76.19 & 44.78 & $78.26^{\mathrm{a}}$ & $81.73^{\mathrm{a}}$ & $13.07^{\mathrm{b}}$ & $67.24^{\mathrm{a}}$ & $2978.93^{\mathrm{a}}$ \\
\hline $\mathrm{T} 4$ & $63.37^{\mathrm{bc}}$ & $66.35^{\mathrm{b}}$ & 75.44 & 45.73 & $73.54^{\mathrm{bc}}$ & $77.79^{\mathrm{b}}$ & $13.37^{\mathrm{a}}$ & $66.39^{\mathrm{ab}}$ & $2941.17^{\mathrm{ab}}$ \\
\hline $\mathrm{T} 5$ & $58.74^{\mathrm{e}}$ & $61.94^{\mathrm{c}}$ & 75.09 & 44.12 & $73.82^{\mathrm{bc}}$ & $71.29^{\mathrm{d}}$ & $13.03^{\mathrm{b}}$ & $62.50^{\mathrm{c}}$ & $2768.93^{\mathrm{c}}$ \\
\hline T6 & $61.91^{\mathrm{c}}$ & $62.07^{\mathrm{c}}$ & 75.24 & 45.31 & $73.03^{\mathrm{c}}$ & $72.19^{\mathrm{cd}}$ & $13.06^{\mathrm{b}}$ & $62.87^{\mathrm{c}}$ & $2789.19^{c}$ \\
\hline SEM & 0.64 & 0.58 & 0.21 & 0.33 & 0.45 & 0.79 & 0.04 & 0.49 & 21.68 \\
\hline \multicolumn{10}{|l|}{ p-value } \\
\hline Diet effect & $<0.0001$ & $<0.0001$ & 0.71 & 0.81 & 0.0013 & $<0.0001$ & 0.03 & $<0.0001$ & $<0.0001$ \\
\hline Level substitution of PVH effect & 0.002 & $<0.0001$ & 0.47 & 0.78 & 0.06 & $<0.0001$ & 0.05 & $<0.0001$ & $<0.0001$ \\
\hline Galzym additive effect & 0.25 & 0.78 & 0.69 & 0.17 & 0.06 & 0.63 & 0.06 & 0.44 & 0.44 \\
\hline
\end{tabular}

Table 5. Carcass characteristics of growing rabbits fed different experimental diets

\begin{tabular}{|c|c|c|c|c|c|c|c|c|c|c|}
\hline Diet & $\begin{array}{c}\text { Pre- } \\
\text { slaughter } \\
\text { weight }(g)\end{array}$ & $\begin{array}{c}\text { Carcass } \\
\text { weight } \\
\text { (g) }\end{array}$ & $\begin{array}{c}\text { Dressing }^{1} \\
(\%)\end{array}$ & $\begin{array}{c}\text { Liver } \\
\text { weight } \\
\text { (g) }\end{array}$ & $\begin{array}{c}\text { Heart } \\
\text { weight } \\
\text { (g) }\end{array}$ & $\begin{array}{l}\text { Spleen } \\
\text { weight } \\
\text { (g) }\end{array}$ & $\begin{array}{c}\text { Kidney } \\
\text { weight } \\
\text { (g) }\end{array}$ & $\begin{array}{c}\text { Giblets } \\
\text { weight } \\
\text { (g) }\end{array}$ & $\begin{array}{c}\text { Giblets }^{2} \\
(\%)\end{array}$ & $\begin{array}{c}\mathbf{T E P}^{3} \\
(\%)\end{array}$ \\
\hline $\mathrm{T} 1$ & 2071.50 & 1026.70 & 49.56 & 49.0 & 4.03 & 0.97 & 11.15 & 64.18 & 3.10 & 52.56 \\
\hline $\mathrm{T} 2$ & 2196.2 & 1128.5 & 51.38 & 56.65 & 4.66 & 0.87 & 12.10 & 73.41 & 3.34 & 54.77 \\
\hline $\mathrm{T} 3$ & 2348.00 & 1278.30 & 54.44 & 71.70 & 3.90 & 1.04 & 14.30 & 89.90 & 3.83 & 58.32 \\
\hline $\mathrm{T} 4$ & 2238.60 & 1213.30 & 54.20 & 69.68 & 4.24 & 1.23 & 14.74 & 88.66 & 3.96 & 58.21 \\
\hline $\mathrm{T} 5$ & 2104.70 & 1160.00 & 55.11 & 58.15 & 4.28 & 0.97 & 13.00 & 75.43 & 3.58 & 58.75 \\
\hline T6 & 2319.80 & 1256.70 & 54.17 & 72.69 & 4.71 & 1.28 & 13.19 & 90.59 & 3.91 & 58.13 \\
\hline SEM & 51.67 & 37.47 & 0.92 & 3.42 & 0.12 & 0.06 & 0.39 & 3.74 & 0.13 & 0.92 \\
\hline \multicolumn{11}{|l|}{ p-value } \\
\hline Diet effect & 0.63 & 0.44 & 0.34 & 0.24 & 0.31 & 0.05 & 0.05 & 0.18 & 0.35 & 0.34 \\
\hline $\begin{array}{l}\text { Level substitutior } \\
\text { of PVH effect }\end{array}$ & 0.48 & 0.15 & 0.06 & 0.08 & 0.37 & 0.06 & 0.05 & 0.06 & 0.07 & 0.02 \\
\hline $\begin{array}{l}\text { Galzym } \\
\text { additive effect }\end{array}$ & 0.48 & 0.57 & 0.81 & 0.34 & 0.05 & 0.6 & 0.52 & 0.31 & 0.39 & 0.70 \\
\hline
\end{tabular}

Mean values with different superscript letters in a column are significantly different $(\mathrm{p}<0.05)$. PVH: Peanut vein hay. T1, control diet without Galzym; T2, control diet with Galzym; T3, 25\% PVH without Galzym; T4, 25\% PVH with Galzym; T5, 50\% PVH without Galzym and T6, 50\% PVH with Galzym. SEM: Standard error of mean. ${ }^{1}$ Dressing $(\%)=$ carcass weight/Pre- slaughter weight $x 100$; ${ }^{2}$ Giblets $\%=[($ liver + kidney + heart $) /$ Preslaughter weight $] \times 100 ;{ }^{3}$ Total edible parts $(\mathrm{TEP}, \%)=[$ (carcass weight + giblets weight $) /$ Pre-slaughter weight $] \times 100$ 
Table 6. Economic efficiency of inclusion peanut vein hay and Galzym additive in rabbit diets

\begin{tabular}{lcccccc}
\hline \multirow{2}{*}{ Items } & \multicolumn{3}{c}{ Experimental diets } \\
\cline { 2 - 7 } & T1 & T2 & T3 & T4 & T5 & T6 \\
\hline Total average weight (kg) & 1.31 & 1.42 & 1.51 & 1.50 & 1.34 & 1.39 \\
Price of 1 kg body weight (LE) & 38 & 38 & 38 & 38 & 38 & 38 \\
Selling price/rabbit (LE)(A) & 49.78 & 53.96 & 57.38 & 57.00 & 50.92 & 52.82 \\
Total feed intake (kg) & 4.44 & 4.56 & 5.18 & 4.99 & 4.55 & 4.81 \\
Price/kg feed(LE) & 3.58 & 3.62 & 3.33 & 3.37 & 3.26 & 3.30 \\
Total feed cost/rabbit (LE)(B) & 15.90 & 16.51 & 17.25 & 16.82 & 14.83 & 15.87 \\
Net revenue(LE) & 33.88 & 37.45 & 40.13 & 40.18 & 36.09 & 36.95 \\
Economic efficiency & 213.08 & 226.83 & 232.63 & 238.90 & 243.35 & 232.83 \\
\hline PVH
\end{tabular}

PVH: Peanut vein hay. T1, control diet without Galzym; T2, control diet with Galzym; T3, 25\% PVH without Galzym; T4, 25\% PVH with Galzym; T5, 50\% PVH without Galzym and T6, 50\% PVH with Galzym. ${ }^{1}$ Net revenue1: A - B; ${ }^{2}$ Economical efficiency (\%): (Net revenue / B) $\times 100$.

\section{CONCLUSION}

The present study suggests the replacement of clover hay by the peanut vein hay at 25 and $50 \%$ in growing rabbit diets. The performance, digestibility of nutrients, nutritive value, and carcass traits were improved with two levels of PVH and Galzym additive. Galzym additive improved the economic efficiency in control diet and diet containing the low level of peanut vein hay.

\section{DECLARATIONS}

\section{Authors' contribution}

Doaa M. Saber performed the practical part of the experiment, chemical and statistical analyses. Dr. M. R. Ibrahim and Dr. Manylawi collaborated the main idea and participated in manuscript review. Dr. Marwa A. Suliman collaborated on the main idea and design of the experiment, tabulation of experimental data and drafted the manuscript.

\section{Competing interests}

The authors have declared that no competing interest exists.

\section{REFERENCES}

Amaefule KU, Mbonu UE and Amaka V (2011). Performance and nutrient utilization of growing rabbits fed graded levels of raw Bambara Groundnut [Vigna subterranean (L.) Verdc] offal diets. Pakistan Journal of Nutrition, 10(5):463-469. Available at: http://docsdrive.com/pdfs/ansinet/pjn/2011/463-469.pdf

AOAC (2000). Association of official analytical chemists. Official methods of analysis.14th Edition. Washington, D.C.

Asar MA, Osman M, Yakout HM and Safoat A (2010). Utilization of corn-cob meal and faba bean straw in growing rabbits diets and their effects on performance, digestibility and economical efficiency. Egyptian Poultry Science, 30(2): 415-442. Available at: https://pdfs.semanticscholar.org/e650/d90fc13cb67a5153b5a76779927f2806d61c.pdf

Cheeke PR (1987). Rabbit Feeding and Nutrition.Academic Press, Orlando, Florida USA.

Chiou PWS, Yu B and Lin C (1998). The effect of different fibre components on growth rate, nutrient digestibility, rate of digesta passage and hindgut fermentation in domesticated rabbits. Laboratory Animals, 32(3):276-283. DOI: https://doi.org/10.1258/002367798780559310

Etchu KA, Ngu GT and Yongabi KA (2014). Effect of varying levels of groundnut (Arachis hypogaea) haulms on the growth performance of weaners rabbits (Oryctolagus cuniculus). International Journal of Livestock Production, 5(5): 81-87. Available at: http://www.academicjournals.org/article/article1399977414_Etchu\%20et\%20al.pdf

FAO (2016). FAOSTAT. Available at: http://faostat.fao.org/site/567/DesktopDefault.aspx?PageID=567.

Fekete S (1985). Rabbit feeds and feeding with special regard to tropical condition. Journal of Applied Rabbit Research, 8:167-173.

Heuzé V, Thiollet H, Tran G and Lebas F (2017). Peanut forage. Feedipedia, a programme by INRA, CIRAD, AFZ and FAO. Available at: https://feedipedia.org/node/695

Ibrahim MRM (2000). Efficiency of using peanut hay and carrot-tops hay for feeding growing rabbits. Egyptian Journal of Rabbit Science, 10(1): 147-156. Available at: https://www.cabdirect.org/cabdirect/abstract/20013086680

Iyeghe-Erakpotobor GT, Aliyu R and Uguru J (2006). Evaluation of concentrate, grass and legume combinations on performance and nutrient digestibility of grower rabbits under tropical conditions. African Journal of Biotechnology, 5(20): 2004-2008. Available at: https://www.ajol.info/index.php/ajb/article/view/55929.

Iyeghe-Erakpotobor GT, Okunlola BO and Barje PP (2015). Effect of forage type and level, palm oil supplementation and sex on performance of weaner rabbits. Journal of Animal Production and Research, 27: 145-156. Available at: http://journals.napri.gov.ng/index.php/japr/article/view/33

Lebas F (2004). Reflections on rabbit nutrition with special emphasis on feed ingredients utilization. In: Becerril, C.M. and Pro, A. 
(Editors) Proceedings of the 8th World Rabbit Congress, Puebla. Colegio de Postgraduados, Montecillo, Spain, pp. 686-736. Available at: https://northernpulse.com/uploads/resources/527/rabbit-nutrition-with-emphasis-on-ingredient-utilization.pdf

Li Y and Zhang Y (1998). The effects of sorghum tannin on utilization of nutrients. Chinese Animal Magazine, 34 (4): $24-25$.

Mohamed RA, Abdel-Azeem F, Abdel-Fattah SA and Yacout MHM (2008). Effect of using commercial enzymes to improve diets contained peanut hay on performance of growing rabbits. Journal of Agricultural Science, 4911-4925. Available at: https://www.academia.edu/7230460/effect of using commercial enzymes to improve diets contained peanut hay on perfor mance_of_growing_rabbits

Oloruntola OD and Ayodele SO (2017). Pawpaw leaf meal and exo-enzyme in rabbit diet: effect on haematological and serum biochemical indices. Asian Journal of Advances in Agricultural Research, 2(4): 1-8. Available at: http://www.journalrepository.org/media/journals/AJAAR_62/2017/Sep/Oloruntola242017AJAAR36309..pdf

Omer HA, El Karamany MF, Ahmed SM, Abdel-Magid, SS and Bakry BA (2017). Using field crop by-products for feeding rabbits. Bioscience Research, 14(2): 224-233. Available at: https://www.researchgate.net/publication/326490991_Using_field_crop_byproducts_for_feeding_rabbits

Omer HA, El Karamany MF, Ahmed SM, Abdel-Magid SS, El-Naggar S and Bakry BA (2018). Incorporation field crop residues in rabbit rations. Bulletin of the National Research Centre, 42(1): 27. DOI..org/10.1186/s42269-018-0025-2

Omer HA, Tawila MA and Sawsan MG (2012). Feed and water consumptions, digestion coefficients, nitrogen balance and some rumen fluid parameters of Ossimi sheep fed diets containing different sources of roughages. Life Science Journal, 9(3): 805-816. Available at: http://www.lifesciencesite.com/lsj/life0903/115_8841life0903_805_816.pdf

Perenz JM, Lebas F, Gidenne T, Mertens L, Xiccato G, Parigi-Bini R, Dalle ZA, Cossu ME, Carazzolo A, Villamide MJ et al. (1995). European reference method for In vivo determination of diet digestibility in rabbits. World Science, 3(1): 41-43. DOI: https://doi.org/10.4995/wrs.1995.239

Sarhan MA (2005). Utilization of agricultural and agro-industrial by-products of pea (Pisum sativum) in growing rabbit diets. Egyptian Journal of Rabbit Science, 15(2): 157-172.

Schneider BH and Flatt WP (1975).The evaluation of feeds through digestibility experiments. University of Georgia Press. Available at: https://lib.ugent.be/catalog/rug01:001983743

Steven WD, Hohenboken WD, Cheeke PR, Patton NM and Kennick WH (1981). Carcass and meat characteristics of Flernish Giant and New Zealand White purebred and terminal cross rabbits. The Journal of Applied Rabbit Research, 4: 66. DOI: https://doi.org/10.2527/jas1982.5461169x

Suliman and Marwa A (2012). Effect of enzymes supplement on utilization of lemon and orange pulps in growing rabbit diets. Doctoral Thesis, Cairo University, Egypt, p.105. Available at. http://srv3.eulc.edu.eg/eulc_v5/libraries/start.aspx?ScopeID=1.\&fn=ApplySearch\&SearchIdForm=67821293\&ScopeIDSelect=1 . 4.\&ItemType $=\&$ SearchText1 $=$ Effect+of+enzymes+supplement+on+utilization+of+lemon+and+orange+pulps+in+growing+rabbi

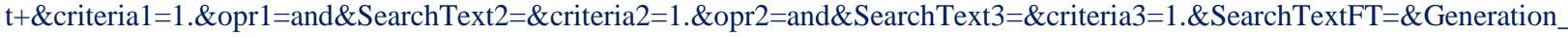
Term $=\&$ BibID $=\&$ PublishYear $=\&$ OrderKey=publishYear+desc $\&$ PageSize $=10$

Tawila M, Omer H and Gad SM (2008). Partial replacing of concentrate feed mixture by potato processing waste in sheep rations. American-Eurasian Journal of Agricultural \& Environmental Sciences, 4(2): 156-164. Available at: http://citeseerx.ist.psu.edu/viewdoc/download?doi=10.1.1.487.7346\&rep=rep1\&type=pdf

Yaakugh, I DI and Tegbe TSB (1990). Performance and carcass characteristics of grower and finisher pigs fed diets containing brewers' dry grain. Nigerian Agricultural Journal, 24: 31-40. 